\title{
The Anarchist Movement in Ukraine at the Height of the New Economic Policy (1924-25)
}

\author{
Viktor Savchenko \\ Odesa State University of Internal Affairs
}

\section{Translated from Ukrainian by Malcolm Archibald}

\begin{abstract}
This paper examines a virtually unknown period of the development of the anarchist movement in Ukraine, ignored by both Soviet and post-Soviet historians, for whom the history of anarchism in the Soviet Union ended in 1921. The author, basing his information on archival materials, including the archives of the Soviet secret police agencies (ChK, GPU, OGPU), extends the life of the anarchist movement through the mid-1920s. This was a period of revitalization of the movement, especially among students, young workers, and the unemployed in the cities of Eastern and Southern Ukraine (Kharkiv, Kyiv, Odesa, Dnipropetrovsk, and Poltava). Despite repression by the government, the anarchist movement in the USSR in the 1920s was able to sustain itself by going underground.
\end{abstract}

Keywords: anarchists, Ukraine, underground, repression, propaganda, leaflets, terror.

$\mathrm{T}$ he mid-1920s was the time of the third chance (if one counts the revolutions of 1905 and 1917 as the first two chances) given by history to East European anarchists to prove their strength. The question of the existence of an anarchist movement in the USSR in the 1920s remains controversial in historiography. Most Soviet historians claimed that anarchism was "totally bankrupt" as early as September 1921 (the date of the "disappearance of the Makhnovshch[y]na") (Iaroslavskii 51, 57). Only the Soviet historian S. Kanev "ventured" to reconsider the process of the "disappearance" of the anarchist movement in the USSR, announcing that "the elimination of pockets of anarchist counterrevolution was not synonymous with the suppression of anarchism generally." He associated the disappearance of anarchism in the USSR with the self-dissolution of the legal All-Russian Anarchist Federation in 1925 (Kanev 401). In modern historiography, two opposing tendencies have emerged with respect to the disappearance of anarchism. According to M. Borovyk, the movement liquidated itself at the beginning of the 1920s. L. Orchakov also limits the existence of anarchism as a political movement to the early 1920s. On the 
other hand, A. Dubovik believes that the anarchist movement in Ukraine persisted into the 1930s.

This article is based on documents of the Soviet secret police agencies from "closed" archives. This source receives corroboration from documents of anarchist provenance (newspapers and other periodicals, letters, and memoirs).

Starting in 1924, it became apparent to both the Chekists and the anarchist leaders that there was a resurgence of the anarchist movement in the USSR, associated with a revival of interest in anarchism among young people especially. The reasons for this were many: disenchantment with NEP and Bolshevik policies, increased unemployment, the "purging" of universities and the civil service, the expansion of political space due to the disappearance of the formerly powerful Socialist-Revolutionary and Menshevik parties, the death of Lenin (which led to a weakening of the central government), and the cessation of famine in Ukraine (which had sapped the forces necessary for struggle). At the same time, the conflicts inside the AUCP(B) (All-Union Communist Party [Bolsheviks]) became harsher: first between the "troika" (Zinov'ev - Kamenev - Stalin) and Trotskii; after 1925, between Stalin and his former allies Zinov'ev and Kamenev. Trotskii in his own campaigns used a number of slogans that were anarchistic in tone, calling for "equal rights for youth," struggle against "the party bureaucracy," and the development of "permanent revolution" (similar to the anarchists' "Third Revolution").

The Ukrainian anarchist renaissance in Left Bank and Southern Ukraine (1924-25) had a definite potential for development, given that the industrial centres of Ukraine in 1904-08 and 1917 were also centres of the anarchist movement in Eastern Europe, and that the anarchists had enjoyed mass support in the Makhnovist movement of 1918-21 and in the movement of workers for the socialization of enterprises in Odesa and in the Donbas in 1917-18 (Savchenko, Anarkhists'kyi rukh; "Anarkhisty ta robitnychyi rukh").

The revival of anarchism in the USSR may also have been connected with the international conjuncture, namely, the Kremlin's plans for world revolution, in which the anarchists were regarded as allies in a multi-faceted struggle with the bourgeois states. A special place in these plans was assigned to the revolution in Germany. In 1922-23 there was a noticeable easing of repression against anarchists in the USSR, accompanied by attempts to recruit anarchist militants and propagandists for work in Germany (Talerov). Anarchists in Ukraine took note of this tendency and tried to make use of it to bolster their own influence.

Neither the Trotskyists nor the Zinovievists evoked the sympathies of the anarchist leaders. The anarchists considered publishing leaflets to explain their "neutrality" vis-à-vis the battle between Stalin and Trotskii (DA00, f.r. 7, op. 1, spr. 409, ark. 8). Anarchists expressed some sympathy 
only for the Sapronovists (the former "Decists"), an oppositional group inside the Russian Communist Party. Although this group was not large, it had adherents in Ukraine (Kharkiv, Odesa, Mykolaiv) (HDA SBU, f. 13, spr. 370, T. 6, ark. 98).

In the mid-1920s at the height of NEP, anarchists criticized the capitalistic features of NEP, the elimination of democratic freedoms, the control over society exercised by the special services, and the repression of the socialist forces, characterizing the regime as "state-capitalist," "restorationist," and fascist-dictatorial. Under no illusions concerning soviets and trade unions, the anarchists regarded them as "affiliated branches" of the dictatorship (Rublev).

In the mid-1920s, the anarchist leader P. Arshinov, in exile in Paris, wrote: "There, in Russia, our movement . . . is gradually beginning to right itself, to come to its senses" (1). A certain "Viktor" wrote from the USSR to the well-known anarchist S. Fleshin in the West that he belonged to "a group of anarchist youth," and that in the Komsomol one could sense a trend "towards the anarchists" (IISH, Senya Fléchine Papers, Folder 79, p. 2). In a letter from an unknown anarchist in the USSR to the anarchist ideologue Voline (V. Eichenbaum), the writer indicated that "recently we have noticed a revival of activity" (IISH, Senya Fléchine Papers, Folder 80, p. 72). Worthy of note is "Obrashchenie Ukrainskoi gruppy $\mathrm{k}$ anarkhicheskim organizatsiiam i otdel'nym tovarishcham v Rossii" ("Appeal of a Ukrainian Group to Anarchist Organizations and Individual Comrades in Russia," 1924), which states that anarchists are renewing contacts between groups, and "have begun the process of unifying," expecting "in the near future to meet (and not only with our comrades from other cities) at an All-Russian Congress of Anarchists" (2).

Similar assessments are found in a report of the 1st Section of the Secret Department (SO) of the OGPU:

Anarchist activity during the reporting period was brisk, tending to both intensify and expand ... during the three-month period, 18 operations were carried out and around 300 anarchists arrested. About 750 individuals in Moscow have been identified; in the Union as a whole, over 4000. ("Sovershenno sekretno," see 1924)

The "All-Union" figures for persons suspected of anarchism provide corroboration for an upsurge in anarchist tendencies.

In 1923 the Chekists recorded intensified activity on the part of the anarcho-syndicalists, who were

in contact with German syndicalists, receiving money from them to carry on their work; they have their own print shops, bookstores, and offices. This current operates both legally and underground. Its leaders are emigrants. 
They work mainly among students. The syndicalists, being better organized and financially stronger than the VFA [All-Russian Federation of Anarchists], are aware of the advantages of unifying the anarchist groups, and draw the VFA into common projects. ("Sovershenno sekretno," see 1923)

A "subsidy" for the anarchist underground in the USSR came from the International Workers' Association-the global federation of anarchosyndicalist unions (Dam'e).

In the summer of 1923, the Chekists found the anarchist counterrevolution taking the following forms:

tossing a cylinder of carbon dioxide into a theatre pit in Kharkiv for the purpose, according to the local anarchist who threw it, of killing the communists and speculators sitting there; anti-Soviet and anti-taxation agitation conducted by individual anarchists in the villages of Podil's'kyi, Poltavs'kyi, and Chernihivs'kyi provinces; attempts to carry out 'exes' [expropriations] in Poltava. ("Sovershenno sekretno," see 1923)

In October 1923 in Odesa, the anarchist M. Kal'ko was put on trial, accused of forming an "underground detachment with the intention of overthrowing the government" in the village of Hladosa. This detachment, with 30 armed insurgents, carried out expropriations and attacked trains, volost executive committees (volispolkomy), and local officials (HDA SBU, f. 13, spr. 415, T. 1, ark. 748, 758).

The general plan of the GPU-eliminating all non-Bolshevik parties by getting them to dissolve themselves-did not work in the case of the anarchists. The anarchists tried to entrench themselves, both in the underground and in legal activities (including Esperanto clubs), and to recruit former members of the Communist Party. State enterprises in Ukrainian cities were hit by a new wave of strikes which had a syndicalist character. In Odesa, Mykolaiv, and Kherson, factories were struck; soldiers and sailors in the ports carried out a general strike. In September-October 1923 strike action affected "almost the whole Donbas," Dnipropetrovsk, Kharkiv, Pervomaisk, and Voznesensk (DA00, f. r. 3, op. 1, spr. 409, ark. 8). The strength of the protest of the unemployed is demonstrated by the events of May 15-21, 1924, in Odesa, when around 5,000 unemployed marched through the city, shouting "down with the government." They drove off the mounted police and stormed the building of the provincial executive committee (hubvykonkom), "seeking a better life and livelihood" ("Samoubiistvo kak protest," 4). Among the leaders of this protest were M. Kyrychenko, M. Handler, Savyts'kyi, Berkovych, and Hertsenzon, identified by police informers as "anarchists-syndicalists." Some of the leaders of the rebellion were arrested and sentenced to exile (DAO0, f. r. 3, op. 1, spr. 1310, ark. 120; HDA SBU, f. 13, spr. 415, T. 2, ark. 80, 92). The involvement of the 
Odesan anarchists in this rebellion is indicated not only by the arrests (75 persons) which took place in their milieu, but also by the formal termination of the activities of the Odesan Federation of Anarchists: "for conspiratorial reasons they dissolved the organization, but secretly continued to take part in meetings of the unemployed" (DA00, f. r. 8065, op. 2, spr. 25916, ark. 173). The anarchist press drew attention to the fact that after the rebellion in Odesa, 16 people were arrested for armed resistance to the GPU during searches and seven of them were executed. S. Zekhtser, the organizer of the anarchist underground in Odesa in 1918, was executed for "banditism" ("Rasstrel bezrabotnykh," 2).

In 1924 the USRR Chekists recorded anarchist groups in 28 cities and towns: Kyiv, Odesa, Kharkiv, Dnipropetrovsk, Zaporizhzhia, Mariupol, Zhytomyr, Kremenchuh, Poltava, Mykolaiv, Kherson, Kamenets-Podilskyi, Vinnytsia, Uman, Bakhmut, Berdiansk, Chernihiv, Kaniv, Simferopol, Sevastopol, Ielyzavethrad, Ialta, Iuzovo, Lubny, Romny, Nizhyn, Radomysl, and the village of Podolky in Romenskyi okruh (HDA SBU, f. 13, spr. 415, T. 2 , ark. 2, 17, 46, 68-80, 92-93, 99; T. 6. ark. 15). But, in reality, there were even more places with anarchist groups.

In Odesa, agents of the GPU identified three anarchist circles among the working class, and a group of "anarchist youth." The Odesan anarchists planned to publish their own journal and start an anarchist library (Savchenko, Neofitsial'naia Odessa 57-58). The archives of the Cheka-GPU include the following statistics for the number of anarchists known to the political police in Odesa: $1921-200$ persons, 1922-109, 1924-135, 1925-50 (HDA SBU. f. 13. spr. 370, T. 1, ark. 748, 758. DA00. f. r. 3, op. 1, spr. 584, ark. 158; spr. 893, ark. 153; f. r.-8065, op. 2, spr. 1187). But there were also dozens of individual anarchists who belonged to "wildcat" groups (independent groups not connected with anarchist centres and authoritative leaders). The Chekists regarded such groups as Esperanto clubs, "hypnosis groups" (the anarchist Tsveif experimented with hypnosis), and the neoTemplarist "Order of Light" (a section of which was active in Kharkiv) as part of the clandestine anarchist movement: "The underground in the student milieu is camouflaged by circles for studying mysticism" ("Sovershenno sekretno," see 1925). A bulletin of the GPU (October 1924) stated that, in spite of arrests, the anarchists were still "trying to be active in certain factories and clubs of garment workers" (IISH, Senya Fléchine Papers, Folder 81, pp. 1-2, 4, 23).

Kharkiv anarchists managed to re-establish a citywide organization on the basis of the "Nabat" platform. They took part in organizing strikes (the "VEK" plant, the Locomotive plant, and in the railway workshops and depots), published hectographed leaflets, planned to set up an underground print shop, and maintained illegal contacts with foreign anarchists as well as anarchists in Moscow, Petrograd, Kyiv, Katerynoslav, Mykolaiv, and Odesa. 
The Kharkiv anarchists were active among civil servants, artisans, and at the Technological Institute. In April 1924,

an operation against the anarchists was launched throughout Kharkiv, culling the leading activists of the Kharkiv anarchists, smashing their editorial collective, and confiscating materials used for publishing journals and May Day leaflets and a host of other organizational materials. ("Sovershenno sekretno," see 1924)

But after the arrests, the Kharkiv anarchists continued their activities by organizing "underground circles of workers ... conducting work among the railway workers" (the group was liquidated), and spreading a proclamation signed by the "Group of worker-anarchists" (HDA SBU, f. 13, spr. 370, T. 1, ark. 82-83). The Kharkiv Federation of Anarchists planned an All-Union congress of anarchists (for July-August 1924), prompting the authorities to arrest approximately 70 Kharkiv anarchists, six of whom were dispatched into exile (Iarutskii 309-10; HDA SBU, f. 13, spr. 415, T. 1, ark. 44).

Anarcho-syndicalists in Kyiv met to discuss unifying the anarchists of the Ukrainian SSR, and "made plans for a campaign against the induction of workers into the ranks of RCP (Russian Communist Party)" ("Sovershenno sekretno," see 1924). In June 1924, a number of Kyiv anarchists were arrested, including 0. Taratuta, N. Drikker, A. Konse, and members of the "Union of Anarchist Youth" (HDA SBU, f. 13, spr. 415, T. 2, ark. 115). Emigrant sources add that anarchists from the construction workers' union in Kyiv were arrested for "speaking out among the workers" (Amerikanskie izvestiia; Golos truda no. 221, no. 228). Arrests of activists belonging to underground anarchist groups took place in Poltava and Iuzovo in the summer of 1924; in Radomysl, Sevastopol, and Ialta in October 1924 (Volna 47; HDA SBU, f. 13, spr. 415, T. 2, ark. 68-79, 109; spr. 283, ark. 32-35).

In 1925 there was a wave of "new arrests of anarchists in connection with their revival" all over the USSR (HDA SBU, f. 13, spr. 415, T. 2. ark. 17 18, 92-120, 128, 205). In Poltava, anarchists conducted propaganda at the vocational and feldsher schools, at the agricultural-cooperative college, among the unemployed and workers in the railway workshops, and in Lubenskyi okrug at the local teacher training courses (Statsenko 212-14; HDA SBU, f. 13, spr. 415, T. 3. ark. 81; T. 4. ark. 30 ob.; T. 8. ark. 9 ob). Groups of anarchist youth were reported in Myrhorodskyi and Prylutskyi okrugs, and in the cities of Hadiach and Romny. There were groups in villages of the Poltava region; they distributed the handwritten underground anarchist journals Anarkhiia (Anarchy) and Vil'na dumka (Free Thought) (HDA SBU, f. 13 , spr. 370, T. 5, ark. 178, 21, 25, 89). In 1925 the case of anarchists of the Poltava region resulted in the arrest of 85 persons; all of the arrested were between the ages of 18 and 25. Despite the 1925 arrests, in the following year the Chekists noted that "the Poltavan anarchists are especially active" 
("Sovershenno sekretno," see 1926). Young people, with the extremism of youth, continued to flock to the black banner, and to populate the jails, political isolators (prisons for political prisoners), and places of exile.

After the Civil War and the establishment of NEP, a spontaneous movement of protest emerged among young people, repelled by the decline in revolutionary morals, the restoration of elements of capitalism, and the Party and Komsomol bureaucracies. Youthful protests sometimes turned into "red banditism" or "red hooliganism," in which young people expressed their discontent in anarchistic fashion by going on a rampage under slogans denouncing betrayers of the workers. Anarchist groups tried to exploit this mood of "spontaneous anarchism" by pitching their leaflets and other publications at a youth audience. The anarchist youth groups which emerged in 1922-25 in Ukraine were mostly autonomous and, indeed, were often far removed from "ideological" anarchism. But they formed part of the anarchist socio-political movement. This movement was distinguished by its spirit, volatility, spontaneity, and breadth. Manifestations of spontaneous anarchism and left extremism were documented in all regions of the USSR in the mid-1920s (Isaev). The emergence of anarchist youth groups on a largescale basis was part of the trend of "leftism" (livatstvo) among Soviet youth. In 1925 arrests of active members of youth groups in opposition to the government took place across the whole USSR; these groups included "Revolutionary Vanguard" (Moscow); the "Volga Group of RevolutionarySocialist Youth" (Nizhnii Novgorod); Left-SR groups in universities of Leningrad, Voronezh, Tomsk, and Orel; and the "Party of Non-Party Students" (Kyiv). The anarchist A. M. Garaseva recalled that in 1925 part of the student milieu was infected with anarchism, and that there were underground groups of anarcho-syndicalists (Garaseva 87, 89, 148). In anarchist circles, the notion of creating an "Anarcho-Communist Association of Youth in Ukraine" was proposed. Anarchist youth groups were noted in Kyiv and Kharkiv, along with the "Anarchist International Association of Working Class Youth 'Buntar'” ("Ob anarkhistakh"). At the Third Congress of the Communist Youth Union of Ukraine, criticisms were voiced concerning the "anarchist and syndicalist attitudes" observed in some young people ("Otchet"). A circular letter issued by the Central Committee of the CP(B)U to the provincial committees (hubkoms) of the Party and the KSMU (the Ukrainian Komsomol) called for struggle against "anarchist vacillating" among youth, and against the formation of "non-party associations of young people" ("Otchet"). In February 1923, student youth in Poltava started the anarchist group "Vanguard," which distributed handwritten postcards addressed to students in the Institute of Popular Education, the Cooperative Academic College, and the local KSMU (Statsenko 214). The government noted the influence of anarchists on the Esperantist movement in Kyiv, Kharkiv, and Odesa. The founders of the Esperantist movement in the Soviet 
republics, S. M. Gaidovskii, O. M. Antonovych (head of the "All-Ukrainian Organization of Esperantists"), and N. Ia. Futerfas (member of the organizing committee of the "All-Russian Esperanto Federation"), were regarded by the Chekists as anarchist agitators (Lins).

Especially worrisome for the authorities were the "extension of the underground"; the attempts of the anarchists to "lead workers' protests" and strikes; their appeals for the organizing of "independent fabzavkoms" (factory-plant committees) and "free trade unions"; their efforts to "subvert the army and the fleet"; their bid to "win popularity" in the villages; and their "intensification of underground activity among students ... anarchism takes root by various means both in the Communist Party and in the Komsomol . . . A significant part of the rising generation is attracted to the ideas and theory of anarchism" ("Sovershenno sekretno," see 1924). Anarchists were active among students and young workers in Dnipropetrovsk (the Mining Institute) and Zaporizhia (HDA SBU, f. 13, op. 1, spr. 415, T. 1, ark. 93, 178). In January 1925 in Bakhmut, members of a "Committee of Revolutionary Action," an anarchist group which organized strikes of miners, were arrested ("Bakhmutskiy komitet deistvii," 4).

In 1925 Chekists established the presence of student-anarchists in two institutions of higher learning in Kyiv: the Institute of People's Education and the Cooperative Higher Technical College. In Odesa, they identified anarchist cells-"fivers" ( $p$ "iatirky)-among students of the Institute of People's Education and the Medical Institute. Conspiratorial "fivers" existed in Odesa in labour collectives of dockers, tailors, milliners, railway and local transport workers, and bakers; in units of the Red Army; and among the unemployed. Acting in an uncoordinated fashion were groups of anarcho-individualists, anarcho-syndicalists, and anarcho-positivists (Golos truzhenika; HDA SBU, f. 13, spr. 370, T. 2, ark. 29-30; DA00, f. r. 3, op. 1, spr. 1328, ark. 22).

In Odesa a group was formed of anarchist political refugeesBessarabists (from Moldova). In 1924 a few Bulgarian anarchists turned up in Odesa: these were political refugees who arrived in the city under the auspices of MOPR (International Red Aid): Zh. Hrozev, D. Kvachev, G. Nikolov, and S. Dzhanzhulev (HDA SBU, f. 13, spr. 415, T. 2, ark. 346). During interrogation in 1936, Hrozev revealed:

When I arrived in the USSR, I found an existing underground organization in Odesa composed exclusively of Bulgarian political refugees ... the Odesa anarchist organization was in contact with foreign anarchist federations, namely, with the French, Serbian, and Bulgarian federations ... they received instructions and material support from abroad for anarchists serving terms of exile in the USSR. (DAOO, f. r. 8065, op. 2, spr. 11704, ark. 13; HDA SBU, f. 13, spr. 370, T. 16, ark. 6) 
The Chekists noted links between the Bulgarian anarchist emigrants in Odesa and Bulgarian anarchist emigrants in France.

The "underground" anarchist groups of Odesa revived somewhat owing to an injection of semi-emigrants from Italy: G. Bucciarelli, R. Cavani, G. Evangelisti, Alboni, E. Herbovets (who organized an assassination attempt in Odesa of the captain of the Italian ship "Cobbe"), D. Serpo, and A. Butiki (DA00, f. r. 7, op. 1, spr. 41, ark. 14, 102; HDA SBU, f. 13, spr. 370, T. 5, ark. $394 \mathrm{ob}$ ). In 1923-26, there was an agricultural commune near Ialta operated by Italian and French anarchists who had emigrated to the USSR. One of its members, the Italian F. Ghezzi, was an active proponent of anarchism (Dolzhanskaia).

The Chekists, confirming the expansion of the underground, noted that anarchist groups "were often composed of from 25 to 60 persons or more." In April 1925, referring to the anarchists, the Chekists stated: "in a significant number of cases their organizations have assumed a mass character" and are "infecting" "certain strata of the working class" ("Sovershenno sekretno," see 1925). In the Politburo of the Russian Communist Party (RCP[B]), a committee chaired by S. Lozovskii, head of the Profintern, devised a plan for the forced expulsion from the USSR of prominent socialists and anarchists being held in prisons and concentration camps (approximately 1,500 people) (Pavlov 72). In June 1925, the GPU conducted an operation to arrest and expel anarchists from Odesa; some of the anarchists were exiled to villages of Kherson region (HDA SBU, f. 13, spr. 415, T. 2, ark. 128).

In June 1925, arrests of anarchists were carried out in Kyiv, after which the Chekists stated that in the city "since the middle of 1925 , anarchist groups no longer exist." And yet, in October 1925 a small group of Kyiv anarchists turned up at the funeral of one of the most seasoned anarchists in the USSR, A. Stepanova (Halaieva) (HDA SBU, f. 13, spr. 415, T. 2, ark. 68-81, $109,160,183,205)$.

An internal bulletin dated December 151925 noted "a boost in the activity level of anarchist groups in a number of districts" and "widespread activity of anarchists." The bulletin warned of "the return of anarchists who had been dispersed" and were now coalescing in groups; about "their activization of work" in the villages; about the anarchists' "special interest in the strict centralization of their actions and the creation of a single centre for Ukraine . . . In Ukraine we are confronted with attempts to merge small groups of individuals into a single Ukrainian party ... Such attempts have already turned up in a whole series of surveillance reports" (HDA SBU, f. 13, spr. 415, T. 2, ark. 38, 46). The GPU determined that "the revival of the anarchist movement is continuing, especially in Moscow and the Central Region, the Northwest, and Ukraine"; in October 1925 "the underground activity of the anarchists is in expansion mode. There are anarchist groups and circles in many regions of the USSR" ("Sovershenno sekretno," see 1925). 
The repressive actions and provocations of the GPU forced the anarchists to cut back their legal activities and retreat to the "deep" underground, using their experience of fighting the tsarist regime. The GPU committed considerable resources to keeping track of the "old cadres" of anarchists, known because of their activities in 1917-21. But these anarchists provided a "screen" for an anarchist underground based on "conspiratorial fives" (into which it was difficult for the GPU to plant provocateurs) and "wildcat" autonomous youth groups. For the anarchist conspiratorial groups, it was important that the punitive organs focused on the activities in the USRR of the 30 to 50 "old" anarchists and overlooked the "wildcat" groups, still not infiltrated by secret informants of the GPU. It is possible this strategy was abetted by the Relief Fund for repressed anarchists, the "Anarchist Black Cross" (Berlin), which worked only with the "old" anarchists, corresponding with them officially through the state postal system, and thereby concentrating the attentions of the Chekists exclusively on them. In the mid-1920s, while carrying on its support for repressed anarchists, the Relief Fund identified between 130 to 150 anarchists in prisons and places of exile in the USSR. But this was only about one-fifth of the number of repressed anarchists; most of the anarchists drawing on the support of the Fund were "old anarchists with a name" (A. Baron, L. Gutman, I. Charin, etc.). The correspondence of anarchists in the USSR with the Relief Fund "levelled off," according to the reports of the GPU (IISH, Senya Fléchine Papers, Folder 79, pp. 1-27).

The Chekists pointed out that the main threat to the government came from "rebellious elements inclined towards terrorism and expropriations," the "most intransigent," who "go underground and try to form a bloc with other anti-Soviet parties" (HDA SBU, f. 13, spr. 283, ark. 3). Bearing in mind the significant combat potential of the anarchists (judging by the numerous terrorist acts committed by them in 1905-08 and 1917-19), the Bolsheviks feared the underground-anarchists would change their tactics and launch a campaign of total terror against the representatives of Soviet power. This issue may have become an urgent concern as a result of a 1924 report by the secret agent M. Spektor, who described secret meetings in Poland of Russian, Polish, Italian, and German anarchists at which a campaign of terror was discussed. The Italian, German, and some of the Russian anarchists (M. Cherniak, Mikhailov) were in favour of a campaign of terror against Soviet leaders, while N. Makhno, V. Voline, and P. Arshinov were against terror, convinced of the necessity "to concentrate our forces for organizational and propaganda work" (Skrypnyk 233-34). The anarchists had neither the forces, means, enthusiasm, nor specific targets in mind for widespread political terror. Rather, they viewed the political system as it had developed in the Soviet republics as the problem, not the individuals managing this system. 
With such information, the Chekists informed the Kremlin: "In Ukraine certain anarchists are considering launching a terror campaign against prominent figures of the Soviet government and the All-Russian Communist Party (ACP[B])" ("Sovershenno sekretno," see 1925). The anarchists of Poltava were accused of only "thinking about terror and exes [expropriations]." In June 1925 the Ukrainian Chekists jauntily reported that "operations carried out in Kyiv and Poltava provinces found weapons, explosives, and illegal literature. Around 100 anarchists were arrested." The punitive organs continued to arrest anarchists in Ukraine in 1925, accusing them of "planning expropriations." In early 1926 the Chekists reported: "During the period in question, the anarchists stepped up their underground activities in Ukraine" (in Poltava, Dnipropetrovsk, Cherkasy, and Odesa okrugs; in Kharkiv and Mariupol; and in the Donbas and Crimea), "mainly among student youth." "In some areas the anarchists are establishing relations with other cities of the Union and abroad" ("Sovershenno sekretno," see 1926).

The administration of the GPU issued an internal memo on the need for classifying anarchists as "active," "passive," "sympathizing," or "former," pointing out that up to this time "information about the anarchists is being generated almost exclusively by OPK (Otdel politicheskogo kontrolia) and foreign intelligence; the network of agents is very weak" (HDA SBU, f. 13, spr. 415, T. 2, ark. 17). The links of some of the anarchists of Kharkiv, Katerynoslav, and the Donbas with "Golos truda" (Moscow), the only legal anarchist publishing house in the USSR, afforded the Chekists with certain information. This publisher kept functioning until 1929, serving as a "trap" for the anarchists (HDA SBU, f. 13, spr. 370, T. 5, ark. 21-29).

Another sign of the revival of the anarchists in 1924-25 was the distribution throughout the cities of the USSR of issues of the Paris anarchist journal Delo truda (The Cause of Labour); the Argentine newspapers Anarkhiia (Anarchy) and Golos truda (The Voice of Labour); and the publications Rassvet (Dawn) and Probuzhdenie (Awakening) from the USA. Also distributed were the illegal publications Prizyv (The Call), Khleb i volia (Bread and Freedom), and the handbill "Rabochiie-anarkhisty" ("Workeranarchists"). The anarchists were discovered to have shapirographs, hectographs, and even a print shop. It was noted that "the distribution of anarchist literature in Ukraine is expanding; underground journals are being published and efforts are being made to set up branches of the 'Golos truda' publishing house." Leaflets "calling for the overthrow of the government" were confiscated at factories in Zaporizhia and Kremenchuk provinces, and in Kharkiv and Odesa (HDA SBU, f. 13, spr. 370, T. 5, ark. 41, 89, 103, 122 ob., 178).

The increasing strength of the anarchist presence in the political life of the Ukrainian SRR in the mid-1920s was reflected in the amount of literature 
being produced, imported, and distributed. Dozens of handwritten tracts, published using shapirographs, as well as newspapers, journals, and leaflets, turned up in Kyiv, Odesa, Dnipropetrovsk, Kharkiv, Poltava, and the Donbas. Agents of the secret police reported propaganda and organizing efforts by the anarchists among circles of young people and workers (Odesa, Poltava, and Kharkiv); the emergence of dozens of new groups of anarchists in cities and villages of the Ukrainian SRR; and the involvement of anarchists in organizing strikes and protest meetings (Odesa, Kyiv, Dnipropetrovsk). ${ }^{1}$

A party structure with a stable membership was not inherent to the anarchist movement. Its strength did not lie in the number of formal members, but rather in its potential to influence the broad masses that might spontaneously come to anarchism. The radicalization of the masses in 190507 and 1917-20 had allowed the anarchist movement to come into its own as a socio-political force. The radicalization of sections of the population of the USSR in the mid-1920s revived the anarchist movement, but the movement was unable to expand its influence on a broad scale under conditions of the consolidation of totalitarianism. The subsequent liquidation of the movement removed any possibility of providing a competing political force in the USSR.

The anarchist "renaissance" in the USSR (especially in the Ukrainian SSR), which showed its potential in 1924-25, had the possibility of reviving the movement destroyed in 1920-21. The anarchists hoped to "stir up" young people, the numerous unemployed, working class radicals, and former Makhnovists, and to start preparing a new revolution in the USSR. The punitive organs detected this tendency and made every effort to localize and gradually, with the use of both small- and large-scale repression, enervate the anarchist underground in the USSR. Subsequently, in 1926-29, the OGPU stepped up its punitive policy against the anarchists, resulting in the suppression of the anarchist movement in Ukraine.

\section{Archives Cited}

Derzhavnyi arkhiv Odes'koi oblasti (DA00). Haluzevyi derzhavnyi arkhiv sluzhby bezpeky Ukrainy (HDA SBU). International Institute of Social History (IISH).

\footnotetext{
${ }^{1}$ See HDA SBU, f. 13, spr. 415, T. 1-8 for publications of the anarchist diaspora: Golos truda (Buenos-Aires), Delo truda (Paris), etc.
} 


\section{Works Cited}

Amerikanskie izvestiia [New York], Sept. 1924, p. 1.

Arshinov, P. A. “Trekhletie 'Delo truda.”' Delo Truda [Paris], no. 37-38, 1928, pp. 1-2.

"Bakhmutskii komitet deistviia." Golos truda [Buenos Aires], no. 244, March 1925, p. 4.

Borovyk, Mykola A. Anarkhists'kyi rukh v Ukraini (1917-1921 rr). Dissertation, Taras Shevchenko National University of Kyiv, 2002.

Dam'e, V. V. "Berlinskii tsentr rossiiskoi anarkhistskoi emigratsii (1920-e gody)." A.I.T., http://aitrus.info/node/2694. Accessed 25 Mar. 2017.

Dolzhanskaia, L. A. “'Ia byl i ostalsia anarkhistom...' (Po materialam sledstvennogo dela Franchesko Getstsi)." Petr Alekseevich Kropotkin i problemy modelirovaniia istoriko-kul'turnogo razvitiia tsivilizatsii: Materialy mezhdunarodnoi nauchnoi konferentsii, edited by P. I. Talerov, Solart, 2005, pp. 238-56.

Dubovik, A. V. "K istorii anarkhistskogo dvizheniia v Ukraine (1922-1938)." Pivdennyi zakhid. Odesika, no. 12, 2011, pp. 182-98.

Garaseva, A. M. Ia zhila v samoi beschelovechnoi strane... Vospominaniia anarkhistki. "Inter Servis," 1997.

Golos truda [Buenos Aires]. no. 221, 23 Aug. 1924, p. 4.

---. no. 228, 11 Oct. 1924 , p 3.

Golos truzhenika [Chicago], no. 23, 1927, p. 1.

Iaroslavskii, Emel'ian. Anarkhizm v Rossii. OGIZ, 1939.

Iarutskii, L. D. Makhno i makhnovtsy, 1995.

Isaev, V. I. "Voenizatsiia molodezhi i molodezhnyi ekstremizm v Sibiri (1920-ye nachalo 1930-kh gg.)." Vestnik NGU. Seriia: Istoriia, Filologiia. T. 1. Vyp. 3: Istoriia, Novosibirsk State University, 2002, pp. 63-70.

Kanev, S. N. Oktiabr'skaia revoliutsiia i krakh anarkhizma (Bor'ba partii bol'shevikov protiv anarkhizma 1917-1922 gg.). Mysl', 1974.

Lins, U. “Drezen, Lanti Kaj 'La Nova Epoko.'” Sennacieca Revuo, no. 115, 1987, pp. 35 52.

“Ob anarkhistakh. Tsirkuliarnoe pis'mo TSK RKP(b)." Vestnik agitatsii i propagandy [Moscow], no. 11-12, 1921, p. 3.

"Obrashchenie Ukrainskoi gruppy $\mathrm{k}$ anarkhicheskim organizatsiiam i otdel'nym tovarishcham v Rossii." Golos truda [Buenos Aires], no. 221, 23 Aug. 1924, p. 2.

Orchakova, Larisa H. Anarkhisty v politicheskoi zhizni Rossii. Dissertation Abstract, Moscow State Pedagogical University, 2008.

“Otchet o III-m S"ezde KSMU," Kommunist (Khar'kov), no. 2, 1921, p. 3.

Pavlov, D. B. Bol'shevistskaia diktatura protiv sotsialistov i anarkhistov. 1917-seredina 1950-kh godov. ROSSPEN, 1999.

"Rasstrel bezrabotnykh." Golos truda [Buenos Aires], no. 217, 26 July 1924, p. 2.

Rublev, Dmitrii I. "Gody stanovleniia SSSR i NEP: Vzgliad anarkhistov." IX Plekhanovskiie chteniia. SSSR 1922-1991 gg. Istoricheskii tupik ili perspektiva istoricheskogo razvitiia?, edited by T. I. Filimanova, Russian National Library (Plekhanov House), 2010, pp. 43-48.

"Samoubiistvo kak protest." Golos truda [Buenos Aires], no. 221, 23 Aug. 1924, pp. 34.

Savchenko, V. A. Anarkhists'kyi rukh v Odesi 1903-1916 rr. Pechatnyi dom, 2014. 
---. "Anarkhisty ta robitnychyi rukh pershoi chverti XX st.: Do postanovky problemy." Materialy 5-oi Mizhnarodnoi nauk.-prakt. konferentsii "Pivden' Ukrainy: Etnoistorychnyi, movnyi, kul'turnyi ta relihiinyi vymiry," International Humanitarian University (Odesa), 2015, pp. 293-97.

---. Neofitsial'naia Odessa epokhi Nepa (Mart 1921-Sentiabr' 1929). ROSSPEN, 2012. Skrypnyk, 0. Za zolotom Nestora Makhna. "Iaroslaviv Val," 2011.

"Sovershenno Sekretno." Lubianka - Stalinu o polozhenii v strane (1922-1934 gg.). Istoricheskie materialy, http://istmat.info/node/11671. Accessed 25 Mar. 2017.

Statsenko, D. V. "Diial'nist' anarkhistiv Poltavy v umovakh stanovlennia bil'shovyts'koi dyktatury (persha polovyna 1920-rokiv)." 3-i Cherevanivs'ki chytannia - Vseukrains'ka konferentsiia: Zbirka naukovykh materialiv, edited by M. I. Stepanenko et al, Poltava National V. G. Korolenko Pedagogical University, 2016, pp. 203-17.

Talerov, P. I. “Komyntern y anarkhysty v 1920-kh-1930-kh hh.” III Konferencja Naukowa "Z Dziejów Anarchizmu," 2-4 June 2016, Szczecin, Poland. Oral Presentation.

Volna [Chicago]. no. 57, 1924, p. 47. 